\title{
The Impacts of Service Quality and Customer Satisfaction in the e-Commerce Context
}

\author{
Yong Lin, Jing Luo, Li Zhou, Petros Ieromonachou, \\ Lin Huang \\ The Business School \\ University of Greenwich \\ London, UK \\ Y.Lin@gre.ac.uk; J.Luo@gre.ac.uk; Li.Zhou@gre.ac.uk; \\ P.Ieromonachou@greenwich.ac.uk; L.Huang@gre.ac.uk
}

\author{
Shuqin Cai \\ School of Management \\ Huazhong University of Science \& Technology \\ Wuhan, China \\ caishuqin@sina.com
}

\begin{abstract}
This paper aims to investigate the impacts of service quality on customer satisfaction and loyalty in the e-commerce context, in particular from a triad view of customer-e-retailer3PL (third party logistics) provider. A literature review is primarily used to determine the conceptual model and to develop the measurement scales. Data were collected through online questionnaire survey conducted in China. Structural equation modeling was used to analyze the collected data and test the proposed research hypotheses. The results indicate that both eservice quality and logistics service quality are strongly linked with customer satisfaction. The research results shown that practitioners (e-retailers) should not only focus on e-service quality, but also the logistics service quality. This research validates the proposed service quality framework with two dimensions (e-service quality and logistics service quality) in ecommerce context. Second, it highlights the impact path of service quality on customer satisfaction and loyalty.
\end{abstract}

Index Terms-Supply chain management, e-service quality, logistics service quality, customer satisfaction, loyalty, ecommerce.

\section{INTRODUCTION}

Along with the fast growth of Internet and its wide application in business, online shopping has grown rapidly in many countries [1]. Electronic commerce (e-commerce) brings huge business opportunities (such as sale product and provide service online) and revenue growth [2] to companies like eretailers, mainly due to its convenient, interactive, lower costs and high degree of customization and personalization to their customers [3]. However, even with the growing number of customers for online shopping, e-commerce is proved to be complicated and difficult more than traditional way of doing business. Improving the service quality of electronic commerce is regarded as one of the key factors leading to success or failure [4].

During the past two decades, service quality in ecommencer context is increasingly recognized as an effective way of gaining and sustaining competitive advantages [5, 6], and a key to customer satisfaction and loyalty [7, 8]. One branch of past researches has focused on e-service quality [9, 10] due to the acceptance and usage of internet technologies in commerce, which differs the interaction and exchange from the traditional business. e-service quality is defined as "the extent to which a Web site facilitates the efficient and effective shopping, purchasing and delivery" [5].

However, this didn't fully reflect the e-commerce experience and the service quality perceived by customers. From a process view, e-service is only the first part that customer perceived during online shopping, covering search and browser product information, and place order online. The other important part is the logistics service [4], while companies either deliver products to customer by themselves, or outsource such service to third party logistics (3PL) provider to accomplish the delivery. Logistics service quality is regarded as an important key to create customer satisfaction [11]. In a recent study, the data show that the most concerned two issues of online shopping are actually logistics-related problems, including long delivery time, the mismatch between the received product and the product specification online [12].

As discussed above, in the context of logistics outsourcing, the online shopping is happened within a service triad consisting of e-retailer, customer, and 3PL provider (see Fig. 1), not a dyad with only e-retailer and customer.

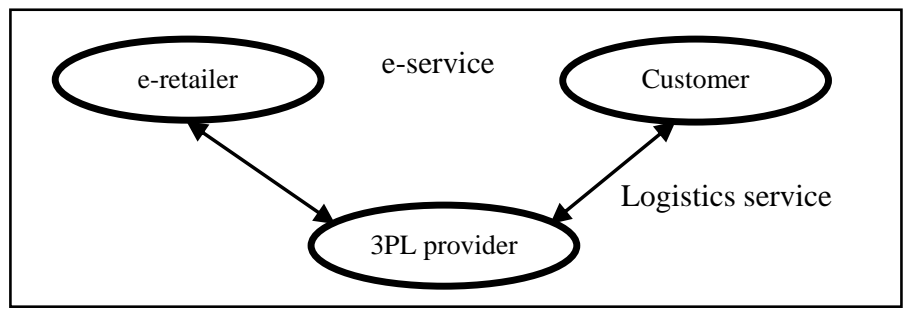

Fig. 1. Service triad of customer-e-retailer-3PL provider in e-commerce context

The perceived service quality of online shopping is much more complicated due to several roles interacted with each other in the service triad $[13,14]$. The perceived service quality from customer is not only decided by the e-service provided by the e-retailer, but also the logistics service offered by 3PL provider. 
In order to better address the triad nature of the online shopping (e-commerce) experience, this research aims to propose a framework of service quality combing e-service quality and logistics service quality, in particularly with a triadic view in order to capture the complex dynamics in the context of e-commerce [13, 15], and to investigate the relationships between service quality and customer satisfaction and customer loyalty.

This research makes two contributions. First, it validates the proposed service quality framework with two dimensions (e-service quality and logistics service quality) in e-commerce context. Second, it highlights the impact path of service quality on customer satisfaction and customer loyalty.

In the following sections, hypotheses related with service quality and customer satisfaction/loyalty are developed through a literature review. Then, results from the study that conducted to test the research hypotheses are presented. Finally, theoretical contribution and management implications are discussed, and future research directions are proposed.

\section{TTHEORETICAL FRAMEWORK AND HYPOTHESES}

\section{A. Service quality and customer satisfaction and loyalty}

Service quality (SQ) has been an important research topic in the marketing literature for some time beginning with the conceptual model developed by [16]. The delivery of high SQ strengthens corporate brands and excellence in the service encounters [17], and contributes to consumer satisfaction.

In the e-commerce context, customer satisfaction is normally defined as 'the customers' comparing applause of an e-commerce enterprise, which causes the customers' repurchase" [18], and it is proven to be positively related to customer loyalty.

\section{B. E-service quality}

The quality of the online business service is considered to be an important driver for the success of B2C e-commerce and companies' differentiation strategy [19], and it is normally referred as electronic service quality (e-SQ) and defined as "the extent to which a web site facilitates efficient and effective shopping, purchasing, and delivery of products and services" [6].

A considerable amount of research has been done on the criteria that consumers used to evaluate e-SQ delivered through the web site. These criteria range from web site design, effectiveness and efficiency of online browse (information availability and search), security issue, online purchase (order transaction), and delivery of goods and services [20], mainly focus on customers' online experience and behaviors [21].

It is expected that e-service quality has positive impacts on customer satisfaction and loyalty, hence there two hypothesis are defined below.

H1: e-service quality directly and positively affects customer satisfaction on e-services.

H2: Customer satisfaction on e-services directly and positively affects customer loyalty on e-services.

\section{Logistics service quality}

Research on logistics service quality can be traced back to 1970 s, but it is found that it is difficult to be measured, particularly in an online shopping context.

In a B2C (business-to-customer) context, three dimensions including availability of products, timeliness of delivery and quality of delivery can be used to measure the physical distribution service quality (PDSQ, [22]). Communication was added as the fourth dimension emphasizing the importance of order status information in improving SQ [23]. While in a business-to-business (B2B) context, PDSQ can be evaluated with three outcome dimensions: availability, timeliness and condition [24]. The PDSQ framework was extended with several other constructs, covering the ordering process and receiving process [11].

This test will test whether logistics service quality has positive effects on customer satisfaction and customer loyalty.

H3: Logistics service quality directly and positively affects customer satisfaction on logistics services.

H4: Customer satisfaction on logistics services directly and positively affects customer loyalty on logistics services.

\section{Conceptual framework}

From a view of the triad in the e-commerce context, the perceived service quality of online shopping is defined with two dimensions: e-service quality and logistics quality. This research investigates how these two factors influences customer satisfaction and loyalty. Figure 2 presents the conceptual framework with the proposed hypotheses in this research.

In order to fully understand the inter-relationship within the service triad as described in Figure 1, the following hypotheses are developed to test their interactions.

HIa: e-service quality directly and positively affects customer satisfaction on logistics services.

$H 1 b$ : e-service quality directly and positively affects customer loyalty on e-services.

Hlc: e-service quality directly and positively affects customer loyalty on logistics services.

$H 2 a$ : Customer satisfaction on e-services directly and positively affects customer loyalty on logistics services.

H3a: Logistics service quality directly and positively affects customer satisfaction on e-services.

$H 3 b$ : Logistics service quality directly and positively affects customer loyalty on e-services.

$H 3 c$ : Logistics service quality directly and positively affects customer loyalty on logistics services.

H4a: Customer satisfaction on logistics services directly and positively affects customer satisfaction on e-services.

$H 4 b$ : Customer satisfaction on logistics services directly and positively affects customer loyalty on e-services.

H5: Customer loyalty on logistics services directly and positively affects customer loyalty on e-services. 


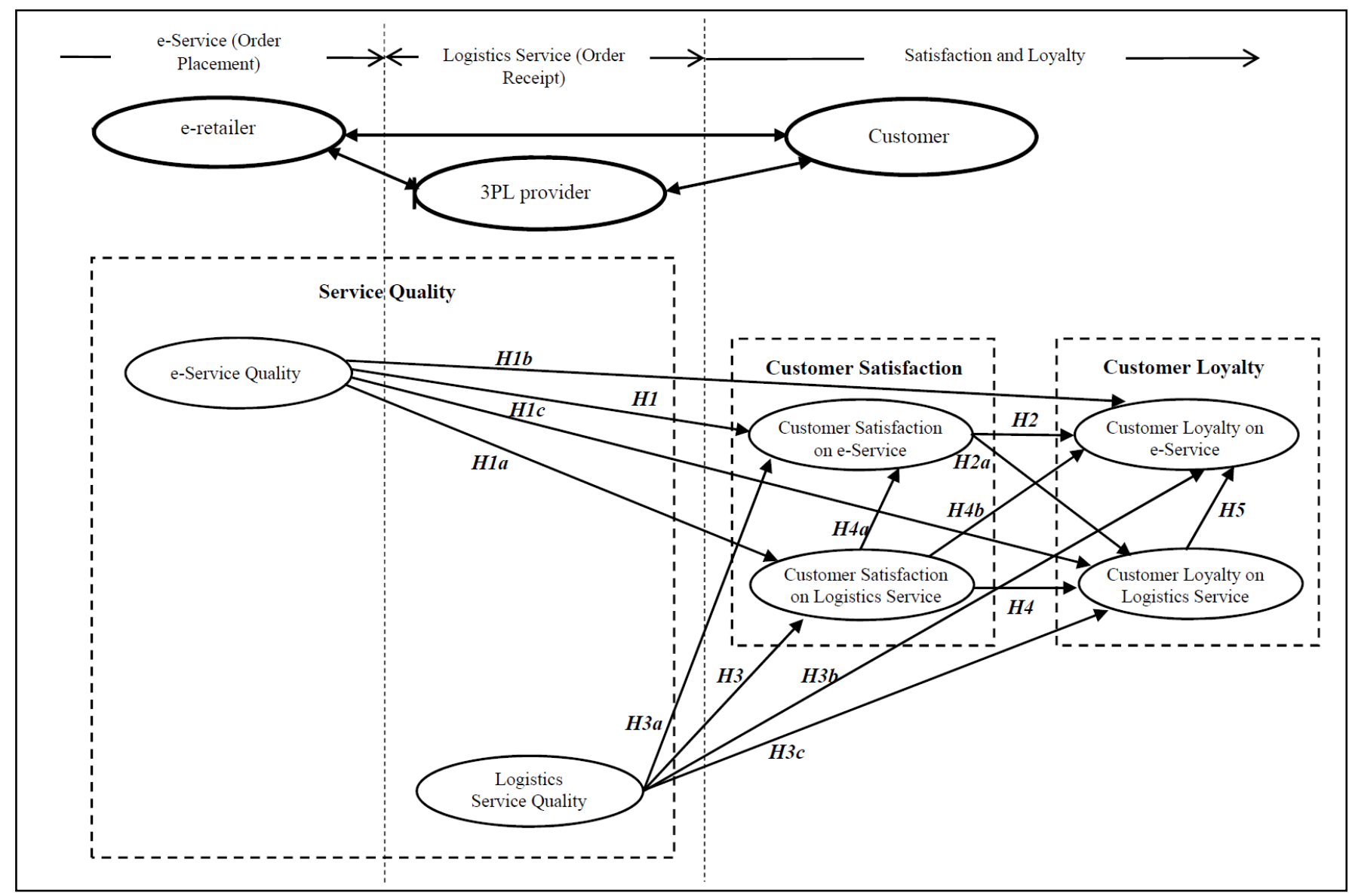

Fig. 2. Conceptual framework of service quality of online shopping in e-commerce context

\section{RESEARCH METHODOLOGY}

A literature review was primarily used to determine the conceptual model and to develop the measurement scales. Data was collected through using the online questionnaire firstly developed as English version and then translated into Chinese. Structural equation modeling was used to data analysis.

\section{A. Measurement Scales}

E-service quality (ESQ) was measured by 5 constructs mainly derived from [8]. Logistics service quality construct was based on [11]. Customer satisfaction was measured by items developed from [8, 11, 25]. Customer loyalty was measured by items generated from [8]. Table I shows the list of measurement constructs and items, and their detailed sources.

All construct items were measured on a seven-point Likertlike scale, ranging from 1 (=strongly disagree) to 7 (=strongly agree).

\section{B. Data collection}

A questionnaire was designed to measure service quality, to evaluate the customer satisfaction and loyalty. The online questionnaire link was sending out to contacts through $Q Q$, which is the most popular social networking tools in China. And these contacts are also asked friendly to pass the questionnaire link to their own contacts. As a result, total number of requests and response rate are not calculated. In total, 699 samples are collected. Table I shows the respondents characteristics. Within 699 respondents, 495 are valid and others are invalid due to uncompleted questions.

Why China was selected for this research is because, as the second largest economy in the world, online shopping grows very fast in China in last few years. The number of Internet users in China has reached 618 million by the end of December 2014, of which the online shoppers amount to 302 million, and this means a continuous growth rate of $24.7 \%$ comparing with 2012 [26]. Moreover, the total market transaction amount of online shopping has hit 1.26 trillion Yuan (RMB) in 2012, with a growth rate of $66.5 \%$ [12].

\section{Reliability and validity}

After data collection, a series of analyses were performed to test the reliability and validity of the constructs based on the sample of 495 respondents.

Reliability of the measurement scale is measured by Cronbach's $\alpha$ [27]. Cronbach's $\alpha$ value for all four measurement scales are all above 0.75 , which shows good reliability of the measurement scales.

Convergent validity is tested by evaluating whether the individual scale item's standardized coefficient is significant or not, which means greater than twice its standard error [28]. As presented in Table III, it reveals that coefficients for all items greatly exceed twice their stand error. Such significance provides evidence of convergent validity for the tested items. 
In addition to convergent validity, to ensure adequacy of the measurement model, discriminant validity should also be evaluated to address the extent to which individual items intended to measure one latent construct do not at the same time to measure a different latent construct [29].

\section{Structural equation modelling method}

In this research, structural equation modeling [28] with AMOS 20.0 is used to estimate the conceptual model as described in Fig. 2, and the analysis is based on the sample of 495 respondents.

TABLE I. RESPONDENTS CHARACTERISTICS (BASES ON 699 SAMPLES)

\begin{tabular}{|c|c|c|c|}
\hline & Category & Frequency & $\begin{array}{c}\text { Percent } \\
(\%)\end{array}$ \\
\hline \multirow[t]{2}{*}{ Gender } & Male & 353 & $51 \%$ \\
\hline & Female & 346 & $49 \%$ \\
\hline \multirow[t]{6}{*}{ Age } & $<19$ & 9 & $1.3 \%$ \\
\hline & $20-29$ & 473 & $67.7 \%$ \\
\hline & $30-39$ & 159 & $22.7 \%$ \\
\hline & $40-49$ & 39 & $5.6 \%$ \\
\hline & $50-59$ & 17 & $2.4 \%$ \\
\hline & $60-69$ & 2 & $0.3 \%$ \\
\hline \multirow{7}{*}{$\begin{array}{l}\text { Monthly } \\
\text { average } \\
\text { amount of } \\
\text { online } \\
\text { shopping } \\
\left(\text { RMB }^{*}\right)\end{array}$} & $<50$ & 97 & $14.16 \%$ \\
\hline & $50-99$ & 94 & $13.72 \%$ \\
\hline & $100-199$ & 149 & $21.75 \%$ \\
\hline & $200-299$ & 90 & $13.14 \%$ \\
\hline & $300-399$ & 67 & $9.78 \%$ \\
\hline & $400-499$ & 28 & $4.09 \%$ \\
\hline & $>500$ & 160 & $23.36 \%$ \\
\hline \multirow{6}{*}{$\begin{array}{l}\text { Most-visited } \\
\text { website for } \\
\text { online } \\
\text { shopping }\end{array}$} & Amazon & 36 & $5.26 \%$ \\
\hline & eBay & 4 & $0.58 \%$ \\
\hline & Taobao & 505 & $73.72 \%$ \\
\hline & Dangdang & 26 & $3.8 \%$ \\
\hline & Jingdong & 82 & $11.97 \%$ \\
\hline & Others & 32 & $4.67 \%$ \\
\hline \multirow{10}{*}{$\begin{array}{l}\text { Most-bought } \\
\text { product } \\
\text { category }\end{array}$} & Books & 87 & $12.7 \%$ \\
\hline & Music/Games/Film & 2 & $0.29 \%$ \\
\hline & Electronics & 83 & $12.12 \%$ \\
\hline & Computer \& Office & 26 & $3.8 \%$ \\
\hline & Home/Garden/Pets & 24 & $3.5 \%$ \\
\hline & Toys/Children/Baby & 32 & $4.67 \%$ \\
\hline & Clothes/Shoes/Watches & 351 & $51.24 \%$ \\
\hline & Sports/Outdoors & 15 & $2.19 \%$ \\
\hline & Grocery/Health/Beauty & 62 & $9.05 \%$ \\
\hline & DIY/Tools/Car & 3 & $0.44 \%$ \\
\hline
\end{tabular}

(*Notes: RMB Yuan, during the data collection period, the exchange rate is USD/CNY: 6.117(low)-6.196(high))

\section{EMPIRICAL ANALYSIS AND RESULTS}

\section{A. Hypotheses testing with structural model}

Table II provides a summary of the goodness of fit statistics.

TABLE II. Fit Statistics of Structural Model

\begin{tabular}{|c|c|c|}
\hline \multirow{2}{*}{ Fit statistics } & \multicolumn{2}{|c|}{ Overall fit measure } \\
\cline { 2 - 3 } & Notation & Model value \\
\hline $\begin{array}{c}\text { Chi-square to degrees of } \\
\text { freedom }\end{array}$ & $x^{2} /$ d.f. & $\begin{array}{c}2.607\left(x^{2}=3937.175 ;\right. \\
d . f .=1510)\end{array}$ \\
\hline $\begin{array}{c}\text { Root mean square error of } \\
\text { approximation }\end{array}$ & RMSEA & 0.053 \\
\hline Root mean square residual & RMR & 0.090 \\
\hline Goodness of fit index & GFI & 0.757 \\
\hline Normed fit index & NFI & 0.868 \\
\hline Comparative fit index & CFI & 0.914 \\
\hline Incremental fit index & IFI & 0.914 \\
\hline
\end{tabular}

As shown in Table II, all the indices are with the recommended range. In particular, with $x^{2} / d f$ less than 3.0 suggested by [30], and RMSEA less than 0.08 according to [31], the measurement model fits well.

As a measure for the goodness-of-fit, this research used incremental fit index (IFI) and comparative fit index (CFI). The IFI and CFI index values for the measurement models are both 0.914 (see Table II) suggesting an adequate fit [32].

The results of hypothesis test using the SEM technique are shown in Table III.

TABLE III. TABLE V. RESULTS OF HYPOTHESIS TEST FOR STRUCTURAL MODEL

\begin{tabular}{|c|c|c|c|c|c|}
\hline Hypothesis & Path & $\begin{array}{c}\text { Path } \\
\text { coefficient }\end{array}$ & S.E. & C.R. & $p$ \\
\hline$H 1$ & $\mathrm{CSE} \leftarrow \mathrm{ESQ}$ & .620 & .066 & 10.201 & $* * *$ \\
\hline H1a & $\mathrm{CSL} \leftarrow \mathrm{ESQ}$ & .202 & .080 & 2.728 & .006 \\
\hline$H 1 b$ & CLE־ESQ & .089 & .057 & 1.725 & .085 \\
\hline$H 1 c$ & 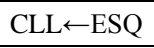 & .092 & .089 & 1.225 & .221 \\
\hline$H 2$ & $\mathrm{CLE} \leftarrow \mathrm{CSE}$ & .718 & .063 & 12.813 & $* * *$ \\
\hline$H 2 a$ & CLL־CSE & .527 & .081 & 7.815 & $* * *$ \\
\hline$H 3$ & $\mathrm{CSL} \leftarrow \mathrm{LSQ}$ & .400 & .085 & 5.304 & $* * *$ \\
\hline$H 3 a$ & $\mathrm{CSE} \leftarrow \mathrm{LSQ}$ & -.116 & .069 & -1.986 & .047 \\
\hline$H 3 b$ & CLE־LSQ & -.071 & .050 & -1.652 & .098 \\
\hline$H 3 c$ & 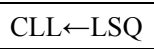 & .098 & .071 & 1.556 & .120 \\
\hline$H 4$ & $\mathrm{CLL} \leftarrow \mathrm{CSL}$ & .138 & .067 & 2.667 & .008 \\
\hline$H 4 a$ & $\mathrm{CSE} \leftarrow \mathrm{CSL}$ & .416 & .062 & 9.637 & $* * *$ \\
\hline$H 4 b$ & $\mathrm{CLE} \leftarrow \mathrm{CSL}$ & -.071 & .062 & -1.959 & .050 \\
\hline H5 & $\mathrm{CLE} \leftarrow \mathrm{CLL}$ & .293 & .068 & 7.591 & $* * *$ \\
\hline
\end{tabular}

(Notes: Significance level are denoted as $* \mathrm{p}<0.05, * * \mathrm{p}<0.01, * * * \mathrm{p}<0.001$ )

The findings for hypothesis $H I$ indicated that e-service quality has positive impacts on customer satisfaction on eservice. Moreover, this customer satisfaction on e-services strongly leads to customer loyalty on the e-services as hypothesis $\mathrm{H} 2$ is being accepted (ESQ $\rightarrow$ CSE $\rightarrow$ CLE). Furthermore, customer satisfaction on e-services has a positive link with customer loyalty with the logistics services as 
indicated through the acceptance of hypothesis $H 2 a$. This also means e-service quality will in-directly affect customer's loyalty on the selected logistics services (ESQ $\rightarrow$ CSE $\rightarrow$ CLL).

Since hypothesis $H I b$ and $H I c$ are both being rejected, that means there a no direct affects between e-service quality and customer loyalty on both e-service and logistics services. However, e-service quality will in-directly impact on customer loyalty on both e-services and logistics services via positive customer satisfaction on e-services as discussed above.

However, hypothesis Hla is accepted, which means to some extent, e-service quality has impact on customer satisfaction with the logistics services. This is an unexpected finding in this research. Furthermore, this indicated that it will in-directly impact on customer loyalty with the logistics services through the positive link between CSL and CLL as indicated by the acceptance of hypothesis $\mathrm{H} 4$. $(\mathrm{ESQ} \rightarrow \mathrm{CSL} \rightarrow \mathrm{CLL})$

As expected, the findings for $H 3$ prove that logistics service quality also has positive impacts on customer satisfaction on logistics services, and this customer satisfaction will impact on customer loyalty on the logistics services as hypothesis $\mathrm{H} 4$ is being accepted (LSQ $\rightarrow$ CSL $\rightarrow$ CLL), but it is not as strong as the customer satisfaction on e-service did on the customer loyalty on the e-service.

However, same as the e-service quality, logistics service quality has no positive impacts on customer satisfaction and loyalty with the e-services as indicated through the rejection of hypothesis $H 3 a$ and $H 3 b$. Meanwhile, with the rejection of hypothesis $H 3 c$, it indicated that logistics service quality has no direct impacts on customer loyalty with the e-services. But logistics service quality will impact on customer loyalty with the logistics services through customer's satisfaction on the logistics service as discussed above.

As indicated by the rejection of hypothesis $H 4 b$, it means customer satisfaction with the logistics services has no direct impacts on customer's loyalty with the e-services. However, it will in-directly impacts on the customer loyalty with e-service with the positive customer satisfaction on e-services $(\mathrm{CSL} \rightarrow \mathrm{CSE} \rightarrow \mathrm{CLE})$ as indicated by the acceptance of hypothesis $H 4 a$. This also means logistics service quality will in-directly influence customer's loyalty on e-services via the path of (LSQ $\rightarrow$ CSL $\rightarrow$ CSE $\rightarrow$ CLE).

Another interesting finding is that, logistics service quality also will impact on customer's loyalty with the e-services through the path of $\mathrm{LSQ} \rightarrow \mathrm{CSL} \rightarrow \mathrm{CLL} \rightarrow \mathrm{CLE}$ due the hypothesis $H 5$ is being accepted.

\section{CONCLUSION}

This research has tested the inter-relationships among service quality (including e-service quality and logistics service quality), customer satisfaction (on both e-services and logistics services), and customer loyalty (on both e-services and logistics services).

For the contribution to the service quality field, this research developed and verified a service quality framework for e-commerce context, the research results have emphasized that service quality should integrate two dimensions including both e-service quality and logistics service quality. This is also a contribution to practitioners.

For the contribution to practice, many e-commerce companies, they have realized the importance of both eservices and logistics services and its quality to their profitability, which is coincide with our research results. And in particular, they have started to develop their own logistics strategies and either manage their logistics by themselves or outsource it to professional third party logistics service providers in order to improve customer satisfaction and loyalty to their e-services to maintain high profitability. With the verified path from the research results, both e-commerce companies and logistics companies could find several effective and efficient ways to improve customer satisfaction and loyalty on their services

One of the limitation of this research is that, the survey is conducted in China only, future data could be collected in other countries to verify whether different cultural backgrounds will impact the research results or not. Comparative studies with results from different countries could be more interesting to global companies in order to improve their global customers' satisfaction and loyalty with their services.

\section{REFERENCES}

[1] J.W.J. Weltevreden, "B2c e-commerce logistics: the rise of collection-and-delivery points in The Netherlands", International Journal of Retail \& Distribution Management, Vol. 36 No. 8, pp. 638-660, 2008.

[2] A.J. Rohm and V. Swaminathan, "A typology of online shoppers based on shopping motivations", Journal of Business Research, Vol. 57 No.7, pp.748-757, 2004.

[3] H. Park and S. Baek, "Measuring service quality of online bookstores with WebQual", Human-Computer Interaction. HCI Applications and Services, Heidelberg: Springer, 2007, pp. 95103.

[4] Y. Yang, P. Humphreys, and R. McIvor, "Business service quality in an e-commerce environment", Supply Chain Management: An International Journal, Vol. 11 No. 3, pp.195 201,2006

[5] V. Zeithaml, "Service excellence in electronic channels", Managing Service Quality, Vol. 12 No.3, pp.135-138, 2002.

[6] V. Zeithaml, A. Parasuraman, and A. Malhotra, "Service quality delivery through web sites: a critical review of extant knowledge", Journal of the Academy of Marketing Science, Vol. 30 No.4, pp.362-375, 2002.

[7] J. Gummerus, V. Liljander, M. Pura, and A. van Riel, "Customer loyalty to content-based websites: the case of an online health care service", Journal of Services Marketing, Vol. 18 No.3, pp.175-86, 2004.

[8] D. Ribbink, A.C.R. van Riel, V. Liljander, and S. Streukens, "Comfort your online customer: quality, trust and loyalty on the internet", Managing Service Quality, Vol. 14 No. 4, pp. 446456, 2004.

[9] S.D. Kurt and B. Atrek, "The classification and importance of E-S-Qual quality attributes: an evaluation of online shoppers, Managing Service Quality, Vol. 22 No. 6, pp. 622-637, 2012.

[10] I. Santouridis, P. Trivellas, and G. Tsimonis, "Using E-S-QUAL to measure internet service quality of e-commerce web sites in 
Greece", International Journal of Quality and Service Sciences, Vol. 4 No. 1, pp. 86-98, 2012.

[11] J.T. Mentzer, D.J. Flint, and T.M. Hult, "Logistics service quality as a segment-customized process", Journal of Marketing, Vol. 65 No. 4, pp. 82-104, 2001.

[12] CNNIC, "Statistical Report on Online Shopping in China 2012", available http://www.cnnic.net.cn/hlwfzyj/hlwxzbg/dzswbg/201304/t2013 0417_39290.htm, accessed 01-05-2013.

[13] T.Y. Choi and Z.H. Wu, "Taking the leap from dyads to triads: Buyer-supplier relationships in supply networks", Journal of Purchasing \& Supply Management, Vol. 15, pp. 263-266, 2009.

[14] Z.H. Wu, T.Y. Choi, and M.J. Rungtusanatham, "Suppliersupplier relationships in buyer-supplier-supplier triads: Implications for supplier performance", Journal of Operations Management, Vol. 28 No. 2, pp. 115-123, 2010.

[15] M.M. Wilhelm, "Managing coopetition through horizontal supply chain relations: Linking dyadic and network levels of analysis", Journal of Operations Management, Vol. 29 No. 7-8, pp. 663-676, 2011.

[16] A. Parasuraman, V.A. Zeithaml, and L.L. Berry, "A concept model of service quality and its implications for future research", Journal of Marketing, Vol. 49, pp.41-50, 1985.

[17] A. Parasuraman, V.A. Zeithaml, and L.L. Berry, "SERVQUAL: a multiple-item scale for measuring customer perceptions of service quality", Journal of Retailing, Vol. 64 pp. 420-450, 1988.

[18] R.E. Anderson and S.S. Srinivasan, "E-satisfaction and eloyalty: a contingency framework", Psychology \& Marketing, Vol. 20 No.2, pp.123, 2003.

[19] J. Santos, "E-service quality: a model of virtual service quality dimensions", Managing Service Quality, Vol. 13 No. 3, pp. 233246, 2003.

[20] A. Parasuraman, V.A. Zeithaml, and A. Malhotra, "E-S-QUAL: a multiple-item scale for assessing electronic service quality", Journal of Service Research, Vol. 7 No. 3, pp. 213-234, 2005.

[21] J. Rowley, "An analysis of the e-service literature: towards a research agenda", Internet Research, Vol. 16 No. 3, pp. 339-359, 2006.
[22] J.T. Mentzer, R. Gomes, and R.E. Krapfel, "Physical distribution service: a fundamental marketing concept?", Journal of the Academy of Marketing Science, Vol. 17 No. 1, pp. 53-62, 1989.

[23] C.J. Emerson and C.M. Grimm, "Logistics and marketing components of customer service: an empirical test of the Mentzer, Gomes and Krapfel model", International Journal of Physical Distribution \& Logistics Management, Vol. 26 No. 8, pp. 29-42, 1996.

[24] C.C. Bienstock, J.T. Mentzer, and M.M. Bird, "Measuring physical distribution service quality", Journal of the Academy of Marketing Science, Vol. 25 No. 1, pp. 31-44, 1997.

[25] I.G. Saura, D.S. Francés, G.B. Contrí, and M.F. Blasco, "Logistics service quality: a new way to loyalty", Industrial Management \& Data Systems, Vol. 108 No. 5, pp. 650-668, 2008 .

[26] CNNIC, "Statistical Report on Internet Development in China, the 33th Survey Report", available at http://www.cnnic.net.cn/hlwfzyj/hlwxzbg/hlwtjbg/201301/P020 140116509848228756.pdf, accessed 28-01-2014.

[27] J.C. Nunnly, "Psychometric Methods", NY: McGraw-Hill, 1978

[28] J.C. Anderson and D.W. Gerbing, "Structural equation modeling in practice: a review and recommended two-step approach", Psychological Bulletin, Vol. 103 No. 3, pp. 411-423, 1988.

[29] R.F. DeVellis, "Scale development: Theory and Applications", Newbury Park: SAGE Publications, 1991

[30] R.P. Bagozzi and Y. Yi, "On the evaluation of structural equation models", Journal of Academy Marketing Science, Vol. 6 No. 1, pp. 54-78, 1998.

[31] M.W. Browne and R. Cudeck, "Alternative Ways of Assessing Model Fit", Newbury Park: Sage Publications, 1993.

[32] L. Hu and P.M. Bentler, "Cutoff criteria for fit indexs in covariance structure analysis: conventional criteria versus new alternatives", Structural Equation Modeling, Vol. 6 No. 1, pp. 1$55,1999$. 